\title{
Gas Emissions from Mixed Coal-BCF Derived Fuel Burned in Industrial Boilers
}

\section{Emisi Gas dari Bahan Bakar Campuran Batu Bara-BCF yang Digunakan pada Boiler Industri}

\author{
Annita Nurhayati ${ }^{1}$, Didin Agustian Permadi ${ }^{1}$ dan Dyah Marganingrum ${ }^{2}$ \\ ${ }^{1}$ Environmental Engineering Major-Faculty of Civil Engineering and Planning, Institut Teknologi Nasional \\ (Itenas), J1. PH. H. Mutofa No. 23, Bandung, 40124 \\ ${ }^{2}$ Research Center for Geotechnology (LIPI), Jl. Cisitu Lama No. 12, Dago, Bandung, 40135 \\ E-mail: didin@itenas.ac.id
}

Diterima 25 Januari 2021, direvisi 25 Februari 2021, disetujui 22 Maret 2021

\begin{abstract}
ABSTRAK
Emisi Gas dari Bahan Bakar Campuran Batu Bara-BCF yang Digunakan pada Boiler Industri. PT. X adalah industri tekstil yang menggunakan bahan bakar batu bara dalam jumlah besar untuk mengoperasikan boiler, yang menghasilkan abu dasar dalam jumlah besar dan dianggap sebagai limbah B3. Dilakukan uji coba awal (initial trials) untuk menggunakan kembali bottom ash yang dicampur dengan agregat kompos dari limbah padat, sehingga menghasilkan biofuel yang disebut sebagai briket biomassa coal fuel (BCF), sebagai bahan bakar pendamping. Uji coba emisi dilakukan menggunakan MRU Optima 7. Dari hasil uji coba emisi, diketahui bahwa konsentrasi SO dari penggunaan 100\% batu bara adalah $150 \mathrm{mg} / \mathrm{Nm} 3$, sedangkan konsentrasi $\mathrm{SO}_{2}$ dari penggunaan bahan bakar batu bara dengan substitusi $10 \% \mathrm{BCF}$ adalah $498,8 \mathrm{mg} / \mathrm{Nm}^{3}$. Konsentrasi $\mathrm{NO}_{2}$ dari pembakaran $100 \%$ batu bara adalah 174,2 mg/ $\mathrm{Nm}^{3}$, sedangkan dari pembakaran bahan bakar campuran adalah 370,3 mg/ $\mathrm{Nm}^{3}$. Konsentrasi $\mathrm{SO}$, dan $\mathrm{NO}$, tidak dikoreksi terhadap oksigen sebesar $6 \%$ karena di dalam Lampiran IV Permen LH No 7 tahun 2007 hal tersebut hanya disyaratkan untuk konsentrasi partikulat. Penggunaan $B C F$ sebagai agregat untuk pembakaran batu bara tidak menurunkan emisi $\mathrm{SO}_{2}$ dan $\mathrm{NO}_{2}$. Faktor emisi $\mathrm{SO}_{2}$ pembakaran $100 \%$ batu bara adalah $6,295 \mathrm{~g} / \mathrm{kg}$ dan faktor emisi $\mathrm{SO}_{2}$ pembakaran batu bara dengan substitusi $\mathrm{BCF} 10 \%$ adalah $31,09 \mathrm{~g} / \mathrm{kg}$. Sedangkan faktor emisi $\mathrm{NO}_{2}$ dari $100 \%$ pembakaran batu bara adalah $7,31 \mathrm{~g} / \mathrm{kg}$ dan faktor emisi $\mathrm{NO}_{2}$ pembakaran batu bara dengan substitusi $10 \% \mathrm{BCF}$ adalah $23,31 \mathrm{~g} / \mathrm{kg}$. Emisi $\mathrm{SO}_{2}$ dan $\mathrm{NO}_{2}$ dari pembakaran bahan bakar campuran batu bara dan $\mathrm{BCF}$ menghasilkan emisi yang lebih tinggi dibandingkan pembakaran batu bara saja. Walaupun emisinya lebih tinggi tetapi konsentrasi emisinya masih di bawah standar emisi nasional saat ini, yakni $750 \mathrm{mg} /$ $\mathrm{Nm}^{3}$ untuk $\mathrm{SO}$, bahan bakar batu bara, 701,43 mg/ $\mathrm{Nm}^{3}$ untuk $\mathrm{SO}_{2}$ bahan bakar campuran, $825 \mathrm{mg} / \mathrm{Nm}^{3}$ untuk $\mathrm{NO}_{2}$ bahan bakar batu bara, dan $816,91 \mathrm{mg} / \mathrm{Nm}^{3}$ untuk $\mathrm{NO}_{2}$ bahan bakar campuran. Hasilnya dapat digunakan sebagai bukti ilmiah dampak kualitas udara penggunaan co-fuel untuk aplikasi boiler industri.
\end{abstract}

Kata kunci: briket, batu bara, cerobong, $\mathrm{SO}_{2}, \mathrm{NO}_{2}$.

\section{ABSTRACT}

Gas Emissions from Mixed Coal-BCF Derived Fuel Burned in Industrial Boilers. The textile industry consumes a huge amount of coal to operate its boiler, resulting in large amounts of bottom ash, considered hazardous waste. PT. X conducted initial trials to reuse bottom ash mixed with solid waste compost to generate biofuel named biomass coal fuel (BCF) briquettes as co-fuel. Emission tests were carried out on the same stack and boiler at PT. X on a different day using MRU Optima 7., From the emission test results, the $\mathrm{SO}_{2}$ concentration of $100 \%$ of coal burning was $150 \mathrm{mg} / \mathrm{Nm}^{3} . \mathrm{SO}_{2}$ concentration of coal fuel with a substitution of $10 \% \mathrm{BCF}$ was $498.8 \mathrm{mg} / \mathrm{Nm}^{3}$. The $\mathrm{NO}_{2}$ concentration from $100 \%$ coal combustion 
was $174,2 \mathrm{mg} / \mathrm{Nm}_{3}$, while from mixed fuel combustion was $370.3 \mathrm{mg} / \mathrm{Nm}^{3}$. Note that oxygen corrections of $6 \%$ for the results of $\mathrm{SO}_{2}$ and $\mathrm{NO}_{2}$ concentrations were not carried out in the experiments. It is relevant only for particulate matter measurement as guided in the Regulation of the Minister of Environment No. 7 of 2007 Annex IV. Using BCF as an aggregate for coal combustion did not bring in lower emissions of $\mathrm{SO}_{2}$ and $\mathrm{NO}_{2}$. The emission factor for $\mathrm{SO}_{2}$ from $100 \%$ coal combustion is $6,295 \mathrm{~g} / \mathrm{kg}$, while coal fuel with a substitution of $10 \% \mathrm{BCF}$ is $31,09 \mathrm{~g} / \mathrm{kg}$. $\mathrm{NO}_{2}$ emission factor from $100 \%$, coal burning is 7,31 $\mathrm{g} / \mathrm{kg}$ while the emission factor of $\mathrm{NO}_{2}$ in coal fuel with a substitution of $10 \% \mathrm{BCF}$ is $23,31 \mathrm{~g} / \mathrm{kg}$. The emissions of $\mathrm{SO}_{2}$ and $\mathrm{NO}_{2}$ from the burning of mixed fuel of coal and BCF yielded higher emissions than the burning of coal alone. Even though the emissions were higher, but the emission concentrations were still below the current national emission standards. The results can be used as scientific evidence of the air quality impact of using co-fuel for industrial boiler applications.

Keywords: briquettes, coal, stack, $\mathrm{SO}_{2}, \mathrm{NO}_{2}$.

\section{Introduction}

In supporting the production process, the textile industry usually uses coal-fired boilers as an energy source. The consumption of coal fuel in the textile industry is carried out in large quantities, up to 27 tons/day. Burning coal in a boiler causes combustion residue, one of which is bottom ash. The textile industry tries to use bottom ash as an alternative fuel, so-called Biomass Coal Fuel (BCF) briquettes, to solve the problem of bottom ash waste generated, with a composition of BCF briquettes $60 \%$ bottom ash and $40 \%$ mixed waste.

In its utilization, BCF briquettes that the textile industry has produced will be used as fuel and coal, or in other words, it is also known as co-firing. Referring to Suganal \& Hudaya (2019), co-firing is the process of burning two types of fuel that are carried out on the same combustion device. Then as comparative data, experiments were also carried out with only the use of coal. Government Regulation No. 22 of the year 2021 stated that bottom ash as co-firing is allowed with technical approval from regulators after specific tests.

Using coal or briquettes as boiler fuel can produce emissions in the form of particulate and gaseous compounds. Based on Minister of Environment Regulation No. 7 of the year 2007, stipulates the quality of emission from stationary source emissions using coal fuel. The regulation stated that the only gas compounds measured are $\mathrm{NO}_{2}$ and $\mathrm{SO}_{2}$, in addition to the measurement of emissions in particulates, pollutants are generally toxic (Sugiarto et al., 2019).

In this study, the emission-quality standard used is the Regulation of the Minister of Environment No. 7 of the year 2007 attachment IV concerning the use of coal fuel and attachment VII concerning the use of co-firing fuels ( $90 \%$ coal and $10 \%$ $\mathrm{BCF}$ ), according to the two experiments conducted. Appendix IV is used because this experiment focuses on gaseous pollutants from coal combustion, using the strictest Quality Standards for Coal. The impact caused by $\mathrm{SO}_{2}$ and $\mathrm{NO}_{2}$ can cause death to humans and animals and cause plants to be wilt and acid rain, which can damage property, such as buildings and other public facilities (Budiyono, 2010). (Suganal dan Hudaya, 2019).

There are negative impacts caused by $\mathrm{SO}_{2}$ and $\mathrm{NO}_{2}$ from the combustion of coal and $\mathrm{BCF}$ briquettes, so data and information are needed regarding gas emissions resulting from the fuel combustion process in the boiler when using coal or BCF briquettes. This study's purpose was limited to measure the concentration of $\mathrm{SO}_{2}$ and $\mathrm{NO}_{2}$ emissions from the use of coal fuel substituted with 
$10 \% \mathrm{BCF}$ and compare it with the emission concentration of coal only. This study is done to see the quality of emissions resulting from the use of $\mathrm{BCF}$, whether the emissions are worse or not. In the future, toxic air pollutants such as particulate matter, heavy metals such as mercury, arsenic etc., polyaromatic hydrocarbons (PAHs), and dioxin should be carefully measured.

\section{Methods}

Briquette is an energy source usually made from biomass which can be used as an alternative fuel. Briquettes can be made with compositions or raw materials that are easy to find, such as coconut shells, rice husks, husk charcoal, wood dust (sawdust), corn cobs, and leaves (Pratama et al., 2018).

The composition of $\mathrm{BCF}$ briquettes consists of $40 \%$ mixed waste and $60 \%$ bottom ash. The bottom ash used is bottom ash which comes from the combustion of coal in the boiler. Meanwhile, the waste used comes from urban waste and waste from the Saguling Dam.

When measuring $\mathrm{SO}_{2}$ and $\mathrm{NO}_{2}$ gas emissions, the Center for Pulp and Paper uses the MRU Optima 7, which refers to the IK-Paskal-LU.MU-03 method for $\mathrm{SO}_{2}$ and IK-Paskal-LU.MU-01 for $\mathrm{NO}_{2}$, the method is based on work instructions belonging to the Pulp and Paper Center (Balai Besai Pulp dan Kertas-Bandung).

Measurements were made on the same boiler and stack, with two experimental arrangements have been made: 1) $100 \%$ coal burning, and 2) 90\% coal $+10 \%$ BCF briquettes. The two experiments' results were compared with the emissions stipulated in the Minister of Environment Regulation Number 7 of 2007, attachment IV and attachment VII.

The combustion and emission tests for each fuel are carried out at different times. For the use of $100 \%$ coal, combustion and emission tests were carried out on 26 February 2020 , while the use of $90 \%$ coal and $10 \%$
BCF was carried out on 9 March 2020. BCF is only used as much as $10 \%$ because it has been assessed from the BCF data produced that this number does not affect the boiler's performance, so the lowest amount is taken, namely $10 \%$. Each emission test is carried out for 1 hour, with data obtained in the form of $\mathrm{SO}_{2}$ and $\mathrm{NO}_{2}$ concentrations from each of the emission tests carried out.

In this experiment for gas emission, no oxygen correction is carried out because it refers to the Minister of Environment Regulation No. 7 of the year 2007 that oxygen correction is only done for particulate emissions only. The MRU Optima 7 manual book is equipped with electrochemical sensors for $\mathrm{O}_{2}, \mathrm{CO}, \mathrm{NO}, \mathrm{NO}_{2}, \mathrm{NO}_{\mathrm{x}}, \mathrm{SO}_{2}$, temperature, and exhaust gas velocity. The MRU Optima 7 is combined with an extraction probe to fit into the stack; the MRU Optima 7 analyzer's internal gas pump will extract a portion of the flue gas from the stack and analyze it using an electrochemical sensor. The thermoelement in the probe tube also measures the temperature of the gas. The results of the measurement of gas emissions in the chimney will be recorded directly in the tool in ppm units (Hintz, 2020).

Finding the core flow will assist in finding the optimal measuring point in the stack. The maximum exhaust gas temperature can identify the core flow. At high reaction times, the analyzer displays the exhaust gas temperature trend. The ways to position the probe in the core flow are as follows:

1. Insert the probe tube slowly into the stack

2. Position the probe when it has reached the maximum exhaust gas temperature

3. The maximum temperature is reached when the sigma on the MRU Optima 7 display disappears, and the sigma with a "beep" stops. One bar is equal to $1^{\circ} \mathrm{C}$.

4. After the core flow is achieved, attach the probe to the probe cone, and the measurement results will appear on the screen. 
Apart from emission concentration data, secondary data is also used, such as coal characteristic data and BCF. In contrast, the actual oxygen concentration data is not used because the gas parameter emission does not require oxygen corrections.

Based on the concentration value obtained from the emission test results, the emission factor calculation for each parameter can be performed. In calculating the emission factors for $\mathrm{NO}_{2}$ and $\mathrm{SO}_{2}$ gases, some supporting data is needed, such as:

- $\mathrm{P}=$ fuel consumption in tonnes/day

- $\mathrm{Q}=$ stack discharge in $\mathrm{m}^{3} /$ second

- $\mathrm{T}=$ length of sampling time in Second

- $\mathrm{K}=$ concentration of parameters in units of $\mathrm{mg} / \mathrm{Nm}^{3}$.

There are three calculation phases:

1. Calculate the variable A (mg/d) using the formula

$$
A=K \times Q
$$

2. Calculate the variable B (gram) using the formula

$\mathrm{B}=\mathrm{A} \times \mathrm{H}$
3. Calculate the emission factor $(\mathrm{g} / \mathrm{kg})$ using the formula

Emission factor $=\frac{B}{P_{\text {Total }}}$

Comparing data used emission factor data from the literature Atmospheric Brown Clouds - Emission Inventory Manual (ABCEIM) (Shrestha et al., 2013).

The emission factors in Table 1 are used to estimate coal emission factors in general based on ABC-EIM.

\section{Results and Discussion}

The fuels used are coal and BCF briquettes. The amount of fuel used can be seen in Table 2.

The characteristics of each fuel can be seen in Table 3.

\section{1. $\mathrm{SO}_{2}$ and $\mathrm{NO}_{2}$ Concentrations}

3.1.1. Sulfur Dioxide $\left(\mathrm{SO}_{2}\right)$

$\mathrm{SO}_{2}$ concentration emission data for coal combustion and coal $+10 \%$ BCF can be seen in Table 4.

Referring to Sukandi et al.(2018), fuels with a high calorific value produce lower

Table 1. Emission Factor (ABC-EIM)

\begin{tabular}{lcc}
\hline \multirow{2}{*}{ Coal Type } & \multicolumn{2}{c}{ Emission Factor $(\mathbf{k g} / \mathbf{T j})$} \\
\cline { 2 - 3 } & $\mathbf{S O}_{2}$ & NOx \\
\hline Lignite & $130 \mathrm{CS}_{\text {fuel }}$ & $300,564^{\mathrm{d}}, 433^{\mathrm{b}, 1}$ \\
\hline
\end{tabular}

Source: Shrestha et al., 2013

Information:

$\mathrm{CS}=$ sulfur content

b, 1 = average value for pulverized coal-fired boiler (uncontrolled)

$\mathrm{d}=$ Kato and Akimoto, 1992. Derived by assuming average calorific values, as given in the IEA Energy Statistics and Balances for non-OECD Countries (IEA, 1998).

Table 2. Amount of The Fuel Consumption

\begin{tabular}{|c|c|c|c|}
\hline \multirow{2}{*}{ Boiler } & \multirow{2}{*}{$\begin{array}{l}\text { Amount of Coal Fuel Before } \\
\text { Substitution of BCF (ton/day) }\end{array}$} & \multicolumn{2}{|c|}{$\begin{array}{c}\text { Total Fuel After Substitution } \\
10 \% \text { BCF (ton/day) }\end{array}$} \\
\hline & & Coal & $\begin{array}{c}\text { Biomass Coal Fuel } \\
\text { (BCF) }\end{array}$ \\
\hline $\begin{array}{l}\text { Experiment 1: Fire tube } \\
\text { boiler }\end{array}$ & 7 & - & \\
\hline $\begin{array}{l}\text { Experiment 2: Fire tube } \\
\text { boiler }\end{array}$ & 6,3 & & 0,7 \\
\hline
\end{tabular}


Table 3. Fuel characteristics

\begin{tabular}{cccccccc}
\hline Sample & $\begin{array}{c}\text { Moisture } \\
\text { content } \\
(\%)\end{array}$ & $\begin{array}{c}\text { Ash } \\
\text { content } \\
(\%)\end{array}$ & $\begin{array}{c}\text { Calorific } \\
\text { value } \\
(\mathbf{c a l} / \mathbf{g})\end{array}$ & $\begin{array}{c}\text { Volatile } \\
\text { matter } \\
(\%)\end{array}$ & $\begin{array}{c}\text { Fixed } \\
\text { carbon } \\
(\%)\end{array}$ & $\begin{array}{c}\text { Total } \\
\text { sulfur } \\
(\%)\end{array}$ & $\begin{array}{c}\text { Nitrogen } \\
(\mathbf{\%})\end{array}$ \\
\hline Coal & 23,15 & 2,65 & $5.223,00$ & 37,00 & 37,13 & 0,24 & 0,19 \\
\hline $\begin{array}{c}\text { Coal }+ \\
10 \% \text { BCF }\end{array}$ & 21,57 & 7,69 & $4.950,78$ & 35,54 & 21,26 & 0,28 & 0,87 \\
\hline
\end{tabular}

Source: Indonesian Institute of Science (LIPI), 2020

Table 4. $\mathrm{SO}_{2}$ concentration

\begin{tabular}{crrr}
\hline Sampling date & Coal $\left(\mathbf{m g} / \mathbf{N m}^{\mathbf{3}}\right)$ & Coal + 10\% BCF $\left(\mathbf{m g} / \mathbf{N m}^{\mathbf{3}}\right)$ & Quality standard \\
\hline $26-02-2020$ & $150,00^{1)}$ & - & $750,00^{2)}$ \\
\hline $09-03-2020$ & - & $493,90^{1)}$ & $701,43^{3)}$ \\
\hline
\end{tabular}

Data source: ${ }^{1)}$ Center for Pulp and Paper, 2020

${ }^{2)}$ Regulation of The Minister of Environment no. 7, attachment IV, 2007

3) Regulation of The Minister of Environment no. 7, attachment VII, 2007

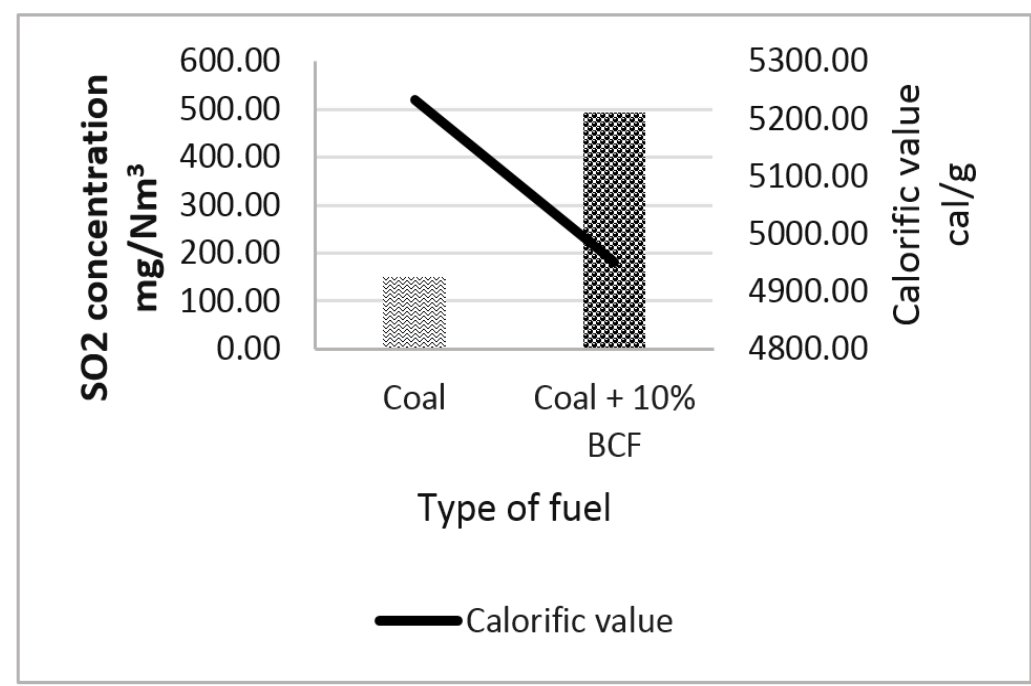

Figure 1. Graph of $\mathrm{SO}_{2}$ Concentration and Calorific Value

gas emissions than fuels with low heating values. As shown in Figure 1, it can be seen that the black line in the image shows a low calorific value in coal fuel $+\mathrm{BCF}$, the $\mathrm{SO}_{2}$ concentration produced by burning coal with a heating value of $5223 \mathrm{cal} / \mathrm{g}$ resulting in an $\mathrm{SO}_{2}$ concentration of $150,00 \mathrm{mg} / \mathrm{Nm}^{3}$. Meanwhile, coal $+10 \%$ by burning with a heating value of $4950,78 \mathrm{cal} / \mathrm{g}$ produces an $\mathrm{SO}_{2}$ concentration of $493,90 \mathrm{mg} / \mathrm{Nm}^{3}$. It is known that based on $\mathrm{Ge}$ (2001), the $\mathrm{SO}_{2}$ concentration for coal briquettes is $701 \mathrm{mg} /$ $\mathrm{Nm}^{3}$. This concentration is relatively greater than the $\mathrm{SO}_{2}$ concentration at PT. X.

Then an analysis is carried out based on the characteristics of each fuel. It can be seen in Table 2 that the sulfur content in coal and coal $+10 \%$ BCF affects the high or low $\mathrm{SO}_{2}$ concentration. The sulfur content in coal is $0,24 \%$, while the sulfur content in coal 
briquettes is $+10 \% \mathrm{BCF}$ which is $0,28 \%$. The transformation of sulfur in coal is also affected by the combustion temperature (Hou et al., 2018). The combustion temperature can be seen in Table 5 .

Table 5. $\mathrm{SO}_{2}$ concentration and burning temperature

\begin{tabular}{lcc}
\hline \multicolumn{1}{c}{ Fuel } & $\mathbf{S O}_{\mathbf{2}}\left(\mathbf{m g} / \mathbf{N m}^{3}\right)$ & $\begin{array}{c}\text { Temperature } \\
\left({ }^{\circ} \mathbf{C}\right)\end{array}$ \\
\hline Coal & 150,00 & $900-1100$ \\
\hline $\begin{array}{l}\text { Coal+10\% } \\
\text { BCF }\end{array}$ & 493,90 & $1200-1300$ \\
\hline
\end{tabular}

According to Hou (2008), when the combustion temperature reaches $300^{\circ} \mathrm{C}, \mathrm{SO}_{2}$ begins to form. Along with the increase in combustion temperature, $\mathrm{SO}_{2}$ will gradually rise and reach its peak at a temperature of around $1100^{\circ} \mathrm{C}$. While the use of coal $+10 \%$ $\mathrm{BCF}$, the temperature tends to increases to $1300^{\circ} \mathrm{C}$. A sulfur oxidation reaction occurs during combustion to produce $\mathrm{SO}_{2}$. In general, the reaction to sulfur dioxide gas $\left(\mathrm{SO}_{2}\right)$ formation is as follows (Nugrainy et al., 2015; Yunita \& Kiswandono, 2017).

$$
\begin{aligned}
& \mathrm{S}+\mathrm{O}_{2} \rightarrow \mathrm{SO}_{2} \\
& \mathrm{SO}_{2}+\mathrm{O}_{2} \rightarrow 2 \mathrm{SO}_{3}
\end{aligned}
$$

The amount of $\mathrm{SO}_{3}$ gas is usually not more than $10 \%$ of the amount of $\mathrm{SO}_{2}$ formation.

\subsubsection{Nitrogen Dioxide $\left(\mathrm{NO}_{2}\right)$}

The emission concentrations of $\mathrm{NO}_{2}$ for both experiments are presented in Table 6.

According to Sugiarto (2019) and Fardiaz (1992), $\mathrm{NO}_{2}$ emissions are influenced by the nitrogen content and volatile matter in the fuel formed during the combustion process. Based on the nitrogen content and volatile matter data in Table 3. These two characteristics do not significantly affect emissions because the value of the content is inversely proportional to the concentration value of $\mathrm{NO}_{2}$.

The $\mathrm{NO}_{2}$ concentration in coal is smaller than the $\mathrm{NO}_{2}$ concentration in coal + $10 \% \mathrm{BCF}$. The $\mathrm{NO}_{2}$ concentration of coal was $174,20 \mathrm{mg} / \mathrm{Nm}^{3}$ while the $\mathrm{NO} 2$ concentration of coal $+10 \%$ BCF was $370,30 \mathrm{mg} / \mathrm{Nm}^{3}$. It is known that based on Komariah (2013), the $\mathrm{NO}_{2}$ concentration for coal is $159,64 \mathrm{mg} /$ $\mathrm{Nm}^{3}$. This concentration is almost equal to that of $\mathrm{NO}_{2}$ coal concentration at PT. X.

As is well-known, nitrogen will burn only at high temperatures. Referring to the EPA (1999), $\mathrm{NO}_{x}$ will quickly be formed from molecular nitrogen in the air, mixed with fuel. The nitrogen in the air will be oxidized together with the fuel and become $\mathrm{NO}_{\mathrm{x}}$ during the combustion process.

A high heating value results in lower gas emissions compared to fuels that have a low heating value. As shown in Figure 2, it can be seen that the black line in the image shows a low calorific value in coal fuel + $\mathrm{BCF}$, the $\mathrm{NO}_{2}$ concentration produced from burning coal with a heating value of 5223,00 $\mathrm{cal} / \mathrm{g}$ resulting in a $\mathrm{NO}_{2}$ concentration of $174,2 \mathrm{mg} / \mathrm{Nm}^{3}$. Meanwhile, burning coal + $10 \%$ BCF with a heating value of 4950,78 cal./g produces a $\mathrm{NO}_{2}$ concentration of $370,30 \mathrm{mg} / \mathrm{Nm}^{3}$.

The calorific value is influenced by moisture content, fixed carbon, and ash content. High water content can reduce combustion temperatures and make it

\begin{tabular}{|c|c|c|c|}
\hline Sampling date & Coal $\left(\mathrm{mg} / \mathrm{Nm}^{3}\right)$ & Coal $+10 \%$ BCF $\left(\mathrm{mg} / \mathrm{Nm}^{3}\right)$ & Quality standard \\
\hline $26-02-2020$ & $174,20^{1)}$ & - & $825,00^{2)}$ \\
\hline $09-03-2020$ & - & $370,30^{1)}$ & $816,91^{3)}$ \\
\hline
\end{tabular}

Table 6. $\mathrm{NO}_{2}$ concentration 


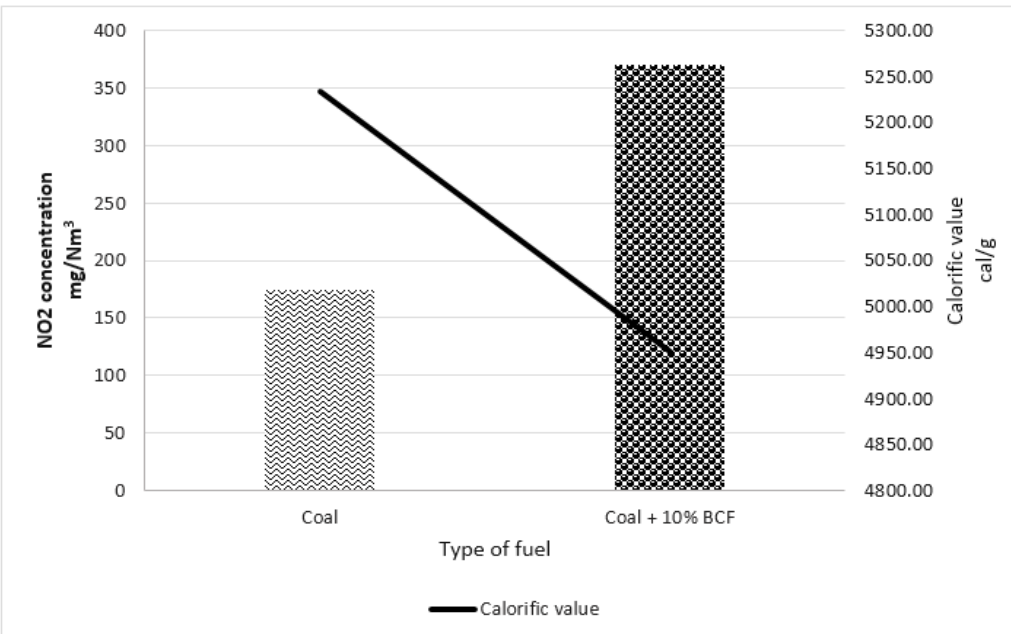

Figure 2. Graph of $\mathrm{NO}_{2}$ Concentration and Calorific Value

difficult to ignite (Himawanto, 2003). The ash content in the fuel plays a role in reducing the calorific value, which lowers the fuel quality. The ash contained in solid fuel is a non-combustible mineral (Yuwono \& Setiawan, 2009). Fixed carbon which is low in fuel, will reduce the calorific value and vice versa (Sudiro, 2014). This statement is by the relationship between calorific value and fixed carbon in coal and the BCF used.

The release of NO increases drastically with increasing combustion temperature (Hou et al., 2018). The combustion temperature can be seen in table 7 .

The formation of $\mathrm{NO}$ from $\mathrm{N}_{2}$ occurs mainly by the formation of thermal $\mathrm{NO}$, as in the following reaction:

Table 7. $\mathrm{NO}_{2}$ concentration and burning temperature

\begin{tabular}{ccc}
\hline Fuel & $\mathbf{N O}_{\mathbf{2}}\left(\mathbf{m g} / \mathbf{N m}^{3}\right)$ & $\begin{array}{c}\text { Temperature } \\
\left({ }^{\circ} \mathbf{C}\right)\end{array}$ \\
\hline Coal & 174,20 & $900-1100$ \\
\hline $\begin{array}{c}\text { Coal }+10 \% \\
\text { BCF }\end{array}$ & 370,30 & $1200-1300$ \\
\hline
\end{tabular}

$\mathrm{O}+\mathrm{N}_{2} \leftrightarrow \mathrm{NO}+\mathrm{O}$

$\mathrm{N}+\mathrm{O}_{2} \leftrightarrow \mathrm{NO}+\mathrm{O}$

$\mathrm{N}+\mathrm{OH} \leftrightarrow \mathrm{NO}+\mathrm{H}$

In the first reaction, thermal NO formation occurs at about $1500^{\circ} \mathrm{C}$. The formation of $\mathrm{N}_{2} \mathrm{O}$ occurs when the combustion temperature reaches 800 $900^{\circ} \mathrm{C}$. During the combustion process, all nitrogen contained in coal will be released as a gas.

According to Hou(2018), $\mathrm{NO}_{2}$ will start to be produced at a combustion temperature of $300^{\circ} \mathrm{C}$ and will increase gradually as the combustion temperature increases with a peak temperature of $1100^{\circ} \mathrm{C}$. While coal + $10 \% \mathrm{BCF}$, the temperature tends to continue to increase to $1300^{\circ} \mathrm{C}$. The reaction to the formation of $\mathrm{NO}$ is a byproduct of the combustion process (Ilahi \& Nugroho). The reaction for the formation of $\mathrm{NO}_{2}$ begins with the formation of $\mathrm{NO}$.

$$
\begin{aligned}
& 2 \mathrm{~N}+\mathrm{O}_{2} \rightarrow 2 \mathrm{NO} \\
& 2 \mathrm{NO}+\mathrm{O}_{2} \rightarrow 2 \mathrm{NO}_{2}
\end{aligned}
$$

\subsection{Emission Factor}

\subsubsection{Sulfur Dioxide $\left(\mathrm{SO}_{2}\right)$}

From the calculations carried out, it is known that the $\mathrm{SO}_{2}$ emission factor is as in Table 8 .

Table 8. $\mathrm{SO}_{2}$ Emission Factor

\begin{tabular}{ccc}
\hline $\begin{array}{c}\text { Coal } \\
(\mathbf{g} / \mathbf{k g})\end{array}$ & $\begin{array}{c}\text { Coal }+\mathbf{1 0 \%} \text { BCF } \\
(\mathbf{g} / \mathbf{k g})\end{array}$ & $\begin{array}{c}\text { ABC-EIM } \\
(\mathbf{g} / \mathbf{k g})\end{array}$ \\
\hline 6,30 & 31,09 & 0,69 \\
\hline
\end{tabular}


In the ABC-EIM literature, the emission factor value of $0,69 \mathrm{~g} / \mathrm{kg}$ for lignite coal type with a sulfur content is $0,24 \%$. The emission factor from coal and coal + $10 \% \mathrm{BCF}$ has an emission factor value that is higher than the emission factor value in $\mathrm{ABC}$-EIM literature.

Table 9. $\mathrm{SO}_{2}$ Emission Factor

\begin{tabular}{lcl}
\hline \multicolumn{1}{c}{ Coal } & $\begin{array}{c}\text { Emission } \\
\text { factor } \\
\mathbf{( g / k g )}\end{array}$ & \multicolumn{1}{c}{ Source } \\
\hline Coal & 6,30 & This study \\
\hline $\begin{array}{l}\text { Coal }+10 \% \\
\text { BCF }\end{array}$ & 31,09 & This study \\
\hline $\begin{array}{l}\text { Coal briquette } \\
\text { (literature) }\end{array}$ & 19,90 & $\begin{array}{l}\text { (Ge } \text { et al. }, \\
\text { 2001) }\end{array}$ \\
\hline $\begin{array}{l}\text { Coal ABC- } \\
\text { EIM }\end{array}$ & 0,69 & $\begin{array}{l}\text { (Shrestha } \text { et } \\
\text { al., 2013) }\end{array}$ \\
\hline
\end{tabular}

Table 9 compares the calculated coal emission factors, coal-based literature, and coal $+10 \%$ BCF.

It can be seen in Table 9 that each fuel used from some literature has a different emission factor value. The coal briquette emission factor, which refers to the journal (Ge et al., 2001), has a value of $19,9 \mathrm{~g} / \mathrm{kg}$, which is smaller than the emission factor value in calculating the $\mathrm{SO} 2$ emission factor of PT. X for coal fuel is $+10 \% \mathrm{BCF}$, but bigger when compared to the value of the ABC-EIM coal and coal emission factors. The briquettes used in journals (Ge et al., 2001) are formulated briquettes.

\subsubsection{Nitrogen Dioxide $\left(\mathrm{NO}_{2}\right)$}

The calculations carried out show that the $\mathrm{NO}_{2}$ emission factor is as in Table 10.

Table 10. $\mathrm{NO}_{2}$ Emission Factor

\begin{tabular}{ccc}
\hline $\begin{array}{c}\text { Coal } \\
(\mathbf{g} / \mathbf{k g})\end{array}$ & $\begin{array}{c}\text { Coal }+\mathbf{1 0} \% \text { BCF } \\
(\mathbf{g} / \mathbf{k g})\end{array}$ & $\begin{array}{c}\text { ABC-EIM (g/ } \\
\mathbf{k g})\end{array}$ \\
\hline 7,31 & 23,31 & 0,01 \\
\hline
\end{tabular}

Suppose the emission factor for coal is $+10 \% \mathrm{BCF}$ and only coal compared to the $\mathrm{ABC}$ literature's emission factor value. In that case, the two emission factors exceed the $\mathrm{ABC}$-EIM emission factor estimate for bituminous coal type is only $0,01 \mathrm{~g} / \mathrm{kg}$. The difference between the two emission factors is relatively much larger when compared to the ABC-EIM emission factors. Table 11 compares the calculated coal emission factors, coal-based literature, and coal + $10 \% \mathrm{BCF}$.

Table 11. $\mathrm{NO}_{2}$ Emission Factor

\begin{tabular}{lcl}
\hline Type of Fuel & $\begin{array}{c}\text { Emission } \\
\text { Factor } \\
(\mathbf{g} / \mathbf{k g})\end{array}$ & \multicolumn{1}{c}{ Source } \\
\hline Coal & 7,31 & This study \\
\hline Coal $+10 \%$ & 23,31 & This study \\
BCF & 0,597 & $\begin{array}{l}\text { (Deru dan } \\
\text { Torcellini, 2007) }\end{array}$ \\
\hline $\begin{array}{l}\text { Coal } \\
\text { (literature) }\end{array}$ & 0,01 & $\begin{array}{l}\text { Shrestha } \text { et al., } \\
\text { Coal (ABC- }\end{array}$ \\
EIM) & & \\
\hline
\end{tabular}

It is known that the $\mathrm{NO}_{\mathrm{x}}$ emission factor for lignite coal is $5,97 \mathrm{~g} / \mathrm{kg}$. Based on Finlayson-Pitts \& Pitts Jr (1986), the $\mathrm{NO}_{2}$ content in $\mathrm{NO}_{\mathrm{x}}$ is $10 \%$ and the $\mathrm{NO}_{2}$ emission based in Der \& Torcellini's (2007) is 0,597 $\mathrm{g} / \mathrm{kg}$. It can be seen in Table 9 above that the emission factor from the use of coal fuel + $10 \% \mathrm{BCF}$ has the greatest emission factor value.

\section{Conclusion}

From these initial trials, the $\mathrm{SO}_{2}$ concentration in coal fuel use is $150 \mathrm{mg} / \mathrm{Nm}^{3}$, and the use of mixed fuel (coal $+10 \% \mathrm{BCF}$ ) is $493,90 \mathrm{mg} / \mathrm{Nm}^{3}$. The $\mathrm{NO}_{2}$ concentration in the use of coal fuel is $174,20 \mathrm{mg} / \mathrm{Nm}^{3}$ while for the use of mixed fuels (coal $+10 \% \mathrm{BCF}$ ) is $370,30 \mathrm{mg} / \mathrm{Nm}^{3}$. The factor that affects the value of gas emissions is the temperature at the time of combustion of the mixed fuel, which tends to increase. The $\mathrm{SO}_{2}$ emission factor is simulated for coal fuel use as 6,30 $\mathrm{g} / \mathrm{kg}$, for the use of mixed fuel (coal $+10 \%$ $\mathrm{BCF}$ ) is simulated as $31,09 \mathrm{~g} / \mathrm{kg}$. The $\mathrm{NO}_{2}$ emission factor for coal fuel use is simulated as $7,31 \mathrm{~g} / \mathrm{kg}$, for mixed fuel (coal $+10 \%$ 
$\mathrm{BCF}$ ) is simulated as $23,31 \mathrm{~g} / \mathrm{kg}$. From the results of the initial trials for an emission test and analyzes that have been carried out, it is known that $\mathrm{SO}_{2}$ and $\mathrm{NO}_{2}$ emissions in the use of coal $+\mathrm{BCF}$ have a concentration or emission factor that is greater than the use of coal only, but the use of BCF can still be done because it still below the quality standard requirements of the Minister of Environment Regulation no. 7 of 2007. However, it is still needed efforts to assess the value of the resulting emissions. Further efforts are still required to collect more stack emission monitoring and statistical analysis on the variations. The composition of $\mathrm{BCF}$ to be added to the coal fuel should be varied to confirm the mixed fuel content's effect on the gas concentrations measured at the stack..

\section{Acknowledgement}

Indonesian Institute of Sciences (LIPI) is highly acknowledged for providing financial and technical supports. The Industry (PT.X) is acknowledged for providing boilers for authors to conduct this experiment. Other parties involved in this study are also thanked for the various supports given during the study implementation.

\section{Authorship}

In this research, the first author collecting data and write the manuscript. Other co-authors revised the manuscript.

\section{References}

Budiyono, A. (2010). Pencemaran udara: dampak pencemaran udara pada lingkungan. Berita Dirgantara, 2(1).

Deru, M. P., dan Torcellini, P. A. (2007). Source energy and emission factors for energy use in buildings: National Renewable Energy Laboratory Golden, CO.

EPA. (1999). Technical Bulletin: Nitrogen Oxides (NOx), Why and How They Are

\section{Controlled. USEPA (Ed.)}

Finlayson-Pitts, B. J., dan Pitts Jr, J. N. (1986). Atmospheric chemistry. Fundamentals and experimental techniques.

Ge, S., Bai, Z., Liu, W., Zhu, T., Wang, T., Qing, S., dan Zhang, J. (2001). Boiler briquette coal versus raw coal: Part I-Stack gas emissions. Journal of the Air \& Waste Management Association, 51(4), 524-533.

Himawanto, D. (2003). Pengolahan limbah pertanian menjadi biobriket sebagai salah satu bahan bakar alternatif. Laporan Penelitian. UNS. Surakarta.

Hintz, E. (2020). User Manual Optima 7. In M. A. fair (Ed.). Neckarsulm: MRU AIR fair.

Hou, J., Ma, Y., Li, S., dan Shang, W. (2018). A comparative study on characteristics of sulfur and nitrogen transformation and gaseous emission for combustion of bituminous coal and char. Carbon Resources Conversion, 1(1), 86-93.

Komariah, L. N. (2013). Kuantifikasi emisi dari pembakaran bahan bakar minyak dan batubara pada boiler industri. Makalah pada Perpustakaan FT UNSRI.

Nugrainy, G. S., Sudarno, S., dan Cahyadi, C. (2015). Upaya Penurunan Emisi $\mathrm{SO}_{2}$ dari bahan bakar batubara kualitas rendah (Tipe: Subbituminous) dengan campuran batu kapur (Limestone) pada proses pembakaran. Diponegoro University.

Pratama, Y. A., Pramudia, A. C., dan Putra, S. S. (2018). Pengaruh variasi komposisi bahan dasar an variasi tekanan terhadap nilai kalor dan temperatur pada briket campuran sekam padi dan batu bara. Universitas 17 Agustus 1945., Universitas 17 Agustus 1945.

Shrestha, R. M., Kim Oanh, N., Shrestha, R., Rupakheti, M., Rajbhandari, S., Permadi, D., Kanabkaew, T., dan Iyngararasan, M. (2013). Atmospheric Brown Clouds: Emission Inventory Manual.

Sudiro, S. S. (2014). Pengaruh komposisi dan ukuran serbuk briket yang terbuat dari batubara dan jerami padi terhadap karakteristik pembakaran. Jurnal Sainstech 
Politeknik Indonusa Surakarta ISSN, 2355-5009.

Suganal, S., dan Hudaya, G. K. (2019). Bahan bakar co-firing dari batubara dan biomassa tertorefaksi dalam bentuk briket (Skala Laboratorium). Jurnal Teknologi Mineral dan Batubara, 15(1), 31-48.

Sugiarto, Herawati, P., dan Riyanti, A. (2019). Analisis Konsentrasi $\mathrm{SO}_{2}, \mathrm{NO}_{2}$ dan partikulat pada sumber emisi tidak bergerak (cerobong) berbahan bakar batubara dan cangkang (Studi Kasus di Kabupaten Muaro Jambi). Jurnal Daur Lingkungan, 2(1), 21-28.
Sukandi, A., Solahuddin, M. I., dan Rasyid, M. K. (2018). Analisis pengaruh perbedaan nilai HHV (High Heating Value) batubara terhadap gas hasil pembakaran pada Boiler.

Yunita, R. D., dan Kiswandono, A. A. (2017). Kajian Indeks Standar Pencemar Udara (ISPU) Sulfur Dioksida $\left(\mathrm{SO}_{2}\right)$ Sebagai polutan udara pada tigas lokasi di kota Bandar Lampung. Analit: Analytical and Environmental Chemistry, 2(1).

Yuwono, J., dan Setiawan, I. B. (2009). Pengaruh penambahan bahan penyala pada briket arang dari limbah serbuk kayu jati. [Yogyakarta]: Universitas Gadjah Mada. 